(PTA Bank), the PTA Reinsurance Company (ZEP-RE), the Clearing House and the COMESA Court of Justice, to provide the required financial infrastructure and service support. COMESA has also promoted a political risk guarantee scheme, the Africa Trade Insurance Agency (ATI), a Leather and Leather Products Institute (LLPI), as well as a cross-border insurance scheme, the COMESA Yellow Card.

Official languages: English, French, Portuguese.

Headquarters: COMESA Secretariat, COMESA Centre,

Ben Bella Road, PO Box 30051, 10101 Lusaka, Zambia.

Website: http://www.comesa.int

Secretary General: Erastus Mwencha (Kenya).

\section{East African Community}

The East African Community (EAC) was formally established on 30 Nov. 1999 with the signing in Arusha, Tanzania of the Treaty for the Establishment of the East African Community. The Treaty envisages the establishment of a Customs Union, as the entry point of the Community, a Common Market, subsequently a Monetary Union and ultimately a Political Federation of the East African States. In Nov. 2003 the EAC partner states signed a Protocol on the Establishment of the East African Customs Union, which came into force on 1 Jan. 2005.

Members. Kenya, Tanzania, Uganda.

Headquarters: PO Box 1096, Arusha, Tanzania.

Website: http://www.eac.int

Secretary General: Nuwe Amanya-Mushega (Uganda).

\section{East African Development Bank (EADB)}

Established originally under the Treaty for East African Cooperation in 1967 with Kenya, Tanzania and Uganda as signatories, a new Charter for the Bank (with the same signatories) came into force in 1980. Under the original Treaty the Bank was confined to the provision of financial and technical assistance for the promotion of industrial development in member states but with the new Charter its remit was broadened to include involvement in agriculture, forestry, tourism, transport and the development of infrastructure, with preference for projects which promote regional co-operation.

Official language: English.

Headquarters: 4 Nile Avenue, Kampala, Uganda.

Website: http://www.eadb.org

Chairman of the Board: Christopher Kassami (Uganda).

\section{Economic Community of Central African States (CEEAC)}

The Economic Community of Central African States (Communauté Economique des Etats de l'Afrique Centrale) was established in 1983 to promote regional economic co-operation and to establish a Central African Common Market. Plans were announced in Jan. 2004 for a free trade zone to be set up by the end of 2007.
Members. Angola, Burundi, Cameroon, Central African Republic, Chad, Democratic Republic of the Congo, Republic of the Congo, Equatorial Guinea, Gabon, Rwanda, São Tomé e Príncipe.

Headquarters: BP 2112, Libreville, Gabon.

President: Denis Sassou-Nguesso (Republic of the Congo). Secretary-General: Louis Sylvain-Goma (Republic of the Congo).

\section{Economic Community of West African States (ECOWAS)}

Founded in 1975 as a regional common market, and now aiming to introduce a single currency in 2009, ECOWAS later also became a political forum involved in the promotion of a democratic environment and the pursuit of fundamental human rights. In July 1993 it revised its treaty to assume responsibility for the regulation of regional armed conflicts, acknowledging the inextricable link between development and peace and security. Thus it now has a new role in conflict management and prevention through its Mediation and Security Council, which monitors the moratorium on the export, import and manufacture of light weapons and ammunition. However, it still retains a military arm, ECOMOG. It is also involved in the war against drug abuse and illicit drug trafficking.

Members. Benin, Burkina Faso, Cape Verde, Côte d'Ivoire, The Gambia, Ghana, Guinea, Guinea-Bissau, Liberia, Mali, Niger, Nigeria, Senegal, Sierra Leone, Togo.

Organization. It meets at yearly summits which rotate in the different capitals of member states. The institution is governed by the Council of Ministers, and has a secretariat in Abuja which is run by an Executive Secretary.

Official languages: English, French, Portuguese.

Headquarters: 60 Yakubu Gowon Crescent, Asokoro, Abuja, Nigeria.

Website: http://www.ecowas.int

e-mail: info@ecowasmail.net

Executive Secretary: Dr Mohamed Ibn Chambas (Ghana).

\section{Intergovernmental Authority on Development}

The Intergovernmental Authority on Development was created on 21 March 1996 and has its origins in the Intergovernmental Authority on Drought and Development, which had been established in 1986. It has three priority areas of co-operation: conflict prevention, management and humanitarian affairs; infrastructure development; food security and environment protection.

Members. Djibouti, Eritrea, Ethiopia, Kenya, Somalia, Sudan, Uganda.

Headquarters: PO Box 2653, Djibouti, Republic of Djibouti. Website: http://www.igad.org

Executive Secretary: Dr Attalla Hamad Bashir (Sudan). 